\section{An Investigation of How Environmental Science Textbooks Link Human Environmental Impact to Ecology and Daily Life}

Yael Wyner, ${ }^{\text {t* }}$ and Rob DeSalle

'Teaching \& Learning, City College of New York, City University of New York, New York, NY 10031;

¥Molecular Systematics, Sackler Institute of Comparative Genomics, Richard Gilder Graduate

School, American Museum of Natural History, New York, NY 10024

\begin{abstract}
Making direct connections between humanity and the environment is of ever-increasing importance in the context of today's environmental crisis. We used qualitative content analysis of precollege- and college-level introductory environmental science textbook case studies to study how they portray humanity's link to the environment. We assessed case studies for how specific and data rich they are and for how they link together daily life, human impact, and ecological interactions. We found that, for many textbooks, case study stories were vaguely drawn and included few data. We also found that, for all textbooks, case studies almost always described human impacts without linking to their ecological underpinnings and daily life connections were frequently missing from human impact discussion. We use comparisons of case studies to make the argument that data and specific details tell more fleshed-out relatable stories, that connecting to daily life will more likely challenge student perceptions of people as separate from the environment, and that explicit inclusion of ecological interactions into environmental stories better explains how people connect to and impact the rest of the living world.
\end{abstract}

\section{INTRODUCTION}

Human impact on the environment is growing at an unprecedented rate at the same time that people of all ages feel increasingly disconnected from the environment (Oosthoek and Gills, 2013; Ceballos et al., 2017). Studies of elementary- through college-level students show that students view people as separate from the environment (Loughland et al., 2002; Shepardson et al., 2007; Moseley et al., 2010; Yavetz et al., 2014) and that they are unable to connect simple daily lived experiences to their environmental impact (e.g., eating hamburgers, using disposable paper cups; Tsurusaki and Anderson, 2010). In addition, studies of teachers, including biology teachers, found that they too show the same distancing from the environment, seeing nature as an environment that lacks people (Moseley et al., 2010; Torkar, 2009).

This view of the environment as lacking people is directly opposed to how scientists see the natural world. They see people as intimately connected to the environment, as part of nature, with human activity affecting ecosystems and ecosystems affecting human well-being (Leopold, 1949; Corvalan et al., 2005; Cardinale et al., 2012). Importantly, the consequences to humanity of human-caused ecosystem degradation are potentially catastrophic, with some researchers warning of an impending global collapse of civilizations (Ehrlich and Ehrlich, 2013).

It is this context of rapid human-caused environmental change and increasing student disconnect from the environment that we chose to study precollege- and college-level introductory environmental science textbook case studies for how they portray humanity's link to the natural world. These introductory environmental
Tammy Long, Monitoring Editor

Submitted Jan 8, 2020; Revised Jul 9, 2020; Accepted Jul 23, 2020

CBE Life Sci Educ December 1, 2020 19:ar54 DOI:10.1187/cbe.20-01-0004

*Address correspondence to: Yael Wyner (ywyner@ccny.cuny.edu).

(c) 2020 Y. Wyner and R. DeSalle. CBE-Life Sciences Education @ 2020 The American Society for Cell Biology. This article is distributed by The American Society for Cell Biology under license from the author(s). It is available to the public under an Attribution-NoncommercialShare Alike 3.0 Unported Creative Commons License (http://creativecommons.org/licenses/ by-nc-sa/3.0).

"ASCB®" and "The American Society for Cell Biology $\circledR^{\prime \prime}$ are registered trademarks of The American Society for Cell Biology. 
science textbooks are designed to introduce students to the environmental science discipline, defined as the study of "the natural world and how humans interact with and impact it" (Karr et al., 2015, p. 5).

The crisis of rapid global environmental change means that making direct connections between humanity and the environment is of ever-increasing importance (Schlosser and Pfirman, 2012; Castree, 2017). The Ecological Society of America (ESA) recently sanctioned a new ecology education framework that highlights the centrality of human impact to ecological interactions, prominently featuring human-environment connections as one of its four dimensions (Berkowitz et al., n.d.). Contextualizing humanity in ecology is a reason why the ESA also advocates for linking energy literacy to ecological literacy. Energy use impacts the ecology of the environment and is also an essential element of daily life (Jablonski et al., 2015). In addition, Hale and colleagues (2017) found that specifically contrasting human-influenced and non-human influenced systems is critical for developing a thorough understanding of how ecological systems function in the real world. Their research explains how contrasting these two systems illuminates underlying concepts. Similarly, we found that directly linking daily life and human impact to ecology improved secondary school student learning of both human impact and ecology (Wyner et al., 2014).

\section{Ecology Disrupted: A Conceptual Model for Environmental Science Learning}

We developed a model for communicating the major theme of environmental science: how people interact with and impact the natural world (Wyner and DeSalle, 2010, 2013; Wyner, 2013, 2015). The goal of this model is for students to learn about the importance and complexity of normal ecological interactions by studying the environmental impacts that result when daily life actions disrupt them. This model uses the same intellectual approach that the field of genetics uses to understand gene function. Geneticists learn gene function by studying the changes in appearance that result from mutations that disrupt normal gene function. In the Ecology Disrupted model, students learn the complexity of intact ecosystems by studying the environmental impacts that result when daily life actions disrupt normal ecological interactions. Using ecological disruption to elucidate the relationship between human environmental impact and daily life unlocks the ecological complexity that connects daily life to human impact and shows students the important role that ecology plays in their lives.

For example, connecting concentrated animal feeding operations (CAFOs) to algal blooms accomplishes the basic goals of environmental science learning-communicating how humans interact with and impact the environment. Taking an additional step of relating these farming practices to a Bolognese sauce cooked at home personalizes the environmental issue to daily life. And finally, going one step further to connect CAFO-created algal blooms to the disruption of the nitrogen cycle contextualizes human action in the ecology of the natural world and highlights the importance of this critical ecological process to natural systems.

Making this direct connection between daily experiences, human impact, and ecological concepts may seem unnecessary, but we documented the difficulties of both students and teach- ers in making these connections. In a study of teachers and elite middle and high school environmental science students, we found that generally neither teachers nor students could connect the food they eat to food webs, even as half of study participants understood that agriculture releases harmful pesticides and fertilizers into the environment (Wyner and Blatt, 2019).

The disconnect from ecosystems shown by students and teachers is also reflected in how textbooks portray the environment. Analysis of photos from a large sample of environmental science textbooks showed that, while they depict many of the environmental issues that urban environments face, they do not depict intact ecosystems, promoting the viewpoint of people as separate from nature (Sullivan, 2008). A critical discourse analysis of a middle grade environmental science textbook made a similar conclusion (Sharma and Buxton, 2015). It found that people were generally absent from pristine ecosystems in this textbook, too. In addition, the authors found that the textbook minimized reference to humans even in heavily impacted ecosystems. For example, according to Sharma and Buxton (2015), the textbook described eutrophication as a passive occurrence, even as humans are the cause of major eutrophication events worldwide. To counteract this separation of people from the environment and promote students' capacities for making connections, textbooks should meaningfully connect these related concepts (van den Broek, 2010).

The Value of Data and Science Stories for Learning Science Telling data-rich stories is another critical requirement for connecting learners to scientific content (Herreid, 2007; Krulwich, 2008; Koch, 2018). Stories with only vague, nonspecific details leave readers disengaged (Buckham, 2015). For this reason, good writing strives for specificity (Cron, 2012). Data are details that fill out a story and make it specific. They are also at the heart of science, with the development of new scientific ideas dependent on data collection or reinterpretation of old data in light of new models (Lederman, 2007). The utility of data to science is also highlighted in the science practices of the Next Generation Science Standards (NGSS Lead States, 2013). In these U.S. K-12 science standards, one practice is explicitly devoted to the analysis and interpretation of data and the other practices are heavily dependent upon data (e.g., developing models, constructing explanations, making arguments from evidence). For better understanding of data and the scientific process, researchers advocate for contextualizing science into case study stories, "stories with an educational message" (Herreid, 2007; Herreid et al., 2011; Lundeberg and Yadav, 2006a,b).

Stories are essential to being human, acting as a universal tool for cognitively engaging with the world (Klassen, 2010; Haidt, 2012). Researchers theorize that stories are important for learning science, because they motivate learners to engage in the topic (Klassen, 2010; Herreid, 2007), bring to life concepts that may otherwise feel abstract (Noddings and Witherell, 1991), and give learning context (Herreid, 2007).

Context is important for learning, because it helps with the construction of new understandings (Vygotsky, 1962). The context stories provide facilitates learning by providing a frame on which to mentally reorganize and integrate prior knowledge and experiences (van den Broek, 2010; Rathburn, 2015). It is for this reason that multiple authors argue for bringing real-world experiences into sustainability learning (Gosselin et al., 2013; 
TABLE 1. Environmental science textbooks analyzed: Analysis was based on textbook sections identified as case studies

\begin{tabular}{|c|c|c|c|}
\hline Author (year) & Name & Publisher & $\begin{array}{l}\text { Number of } \\
\text { case studies }\end{array}$ \\
\hline \multicolumn{4}{|l|}{ High school } \\
\hline Arms (2008) & Environmental Science & Holt, Rinehart, Winston (now McDougal) & $N=21$ \\
\hline Lapinski et al. (2003) & Environmental Science & Scott Foresman-Addison Wesley & $N=10$ \\
\hline Berg et al. $(2013)^{a}$ & Visualizing Environmental Science & $\begin{array}{l}\text { Wiley in collaboration with National } \\
\text { Geographic }\end{array}$ & $N=18$ \\
\hline \multicolumn{4}{|l|}{ College } \\
\hline Christensen (2012) & The Environment and You & Benjamin Cummings, a division of Pearson & $N=19$ \\
\hline $\begin{array}{l}\text { Cunningham and } \\
\text { Cunningham (2013) }\end{array}$ & Environmental Science: A Global Concern & McGraw Hill & $N=26$ \\
\hline Enger and Smith (2016) & Environmental Science: A Study of Interrelationships & McGraw Hill & $N=61^{\mathrm{b}}$ \\
\hline Karr et al., 2015 & $\begin{array}{l}\text { Scientific American Environmental Science for a } \\
\quad \text { Changing World }\end{array}$ & $\begin{array}{l}\text { Freeman in collaboration with Scientific } \\
\text { American }\end{array}$ & $N=25$ \\
\hline Miller and Spoolman (2013) & Environmental Science & Brooks/Cole Cengage Learning & $N=69$ \\
\hline
\end{tabular}

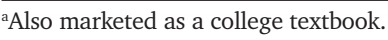

bBoxed sections labeled "Going Green," "Focus On," and "Issues and Analysis," which functioned as case studies, were analyzed as such.

Hale et al., 2017). Sustainability content presented in the context of students' own communities and personal experiences can help learners more readily incorporate new material into their understanding of the world (Premadasa and Bhatia, 2013; Hale et al., 2017).

\section{Rationale for Textbook Analysis}

Textbooks provide a window into how environmental science courses are taught, because they reflect the topics taught in the courses in which they are used (Chiappetta and Fillman, 2007), are ubiquitous across classrooms globally (Valverde et al., 2002; Väljataga and Fiedler, 2014), and are considered to authoritatively represent science topics (Olsen, 1980; Shapiro, 2012; Yoho and Rittmann, 2018). Heavily relied upon in college courses (Bowen and Roth, 2002; Smith et al., 2010), science textbooks are particularly important, because they shape course organization and content (Kesidou and Roseman, 2002; Valverde et al., 2002; Weiss et al., 2003; Sinaga et al., 2017). While reviewing textbooks is not equivalent to observing classroom teaching across a cross-section of instructors, we reasoned that the widespread prevalence of textbooks makes them appropriate proxies for assessing the emphasis and focus of environmental science learning.

The Ecology Disrupted model and other conceptual themes presented here make the case for the learning value of data-rich stories that connect daily life to human impact and ecological interactions. Using this conceptual framework, we asked the following questions about high school-level and college-level environmental science textbook case studies:

1. How specific and data rich are case study stories?

2. How do textbook case studies link together the elements of the Ecology Disrupted framework: Daily Life, Human Impact, and Ecological Interactions?

\section{METHODS}

To answer the study questions exploring the connections that environmental science textbook case studies make among daily life experience, human impact, and ecology, we analyzed case studies from a total of eight introductory environmental science textbooks from the United States (Table 1). Five textbooks are considered college level, two are considered high school level, and one is considered to be a high school-level or college-level text. The sample was selected from a wide range of environmental science introductory texts, because these books are distributed by best-selling educational publishers in the United States. While none of the high school textbooks had been previously reviewed, some of the college-level textbooks had been reviewed (Boersema et al., 2001; Environmental Literacy Council, 2004; Sullivan, 2008). The textbooks all contained case studies that were reviewed and identified by name, chapter, and page number and that then became the subjects of our content analysis.

The analysis focused on one- to two-page-long environmental stories, often labeled as "case studies," that expanded on textbook chapter themes. We determined that these textbook case studies were the most suitable textbook component to investigate. First, sections like these are designed to contextualize learning through detailed stories (Herreid, 2007; Herreid et al., 2011) and would most likely include rich, in-depth descriptions for analysis. Second, after careful review of two textbooks (Arms, 2008; Cunningham and Cunningham, 2013), we found that case studies were the only textbook element that was standardized and easy to identify and locate. In contrast to the lengthy expository narrative of the chapters, they provided appropriately sized bounded units for analysis.

\section{Content Analysis}

The conceptual framework guided our choice of study variables and our study questions about the relationship among variables, hence determining our coding scheme. The documented importance of specificity for engaging storytelling and data for science framed our first study question: How specific and data rich are case study stories? To measure specificity, case studies were evaluated for the presence or absence of text that would make a case study less vague and more specific. We used three commonly present case study features to measure specificity. They are mention of Locations, Dates, and the amount of Data 
presented (Table 2). To better measure each characteristic, multiple nested presence/absence measures were conducted for the same variable. For example, three levels of specificity were measured for Location descriptions. The first level assessed whether a Location was mentioned, even if the location was not the primary focus of the case study. The second level assessed whether a Primary Location was identified, meaning that the location mentioned was central to the case study. The third level focused on whether a Specific Primary Location was mentioned, meaning that that the location mentioned was a named locale with limited boundaries. To be coded as specific, particular locales must have been identified (e.g., Chippewa National Forest in Wisconsin and Minnesota rather than North American forests). If a Specific Primary Location was coded as present, then a Primary Location and Location were also found to be present in the case study.

The second type of specificity measured was for the inclusion of a Date. Case studies were examined to determine whether at least a Generalized Date was mentioned (e.g., in the 2000s), and then, if that feature was coded as present, the case studies were analyzed to determine whether a Specific Date was mentioned. If a Specific Date was coded as present, then a Generalized date was also found to be present in the case study.

The final type of specificity measured was for Data usage. To determine the extent of data usage, case studies were coded for whether they contained: 1) at least two Unrelated Data points, 2) two Relational Data points, or 3) at least three Manipulable Data points. Data points were considered Unrelated if they were about two different topics (e.g., the number of lead pipes in Washington, DC, and the number of children in the U.S. with blood lead levels that exceed standards). Data points were considered Relational if they were related (e.g., children's blood lead levels today as compared with blood lead levels from 40 years earlier). For an item to be considered Manipulable, at least one additional relational data point was required (e.g., the addition of children's blood lead levels from 20 years ago). This Manipulable Data category was created to capture depth of data beyond just two related data points; as such, all graphs and charts were automatically considered to contain Manipulable Data. As in the other items measured, if Manipulable Data were found to be present then Relational Data and Unrelated Data were also considered to be present.

The documented importance of prior experience and the utility of the Ecology Disrupted model for learning guided our second research question, which focused on how textbook case studies link to Daily Life, the first variable in the Ecology Disrupted model. We developed three different parameters (Current, U.S.-Centered, and Everyday Life) to measure the potential of case studies to be personalized to a student's prior Daily Life experiences (Table 2).

While not guaranteed, we made the supposition that Current and U.S.-Centered stories would more likely connect to the lived experience of the textbooks' U.S. target audience than examples from the past and from far away. All case studies that focused on the present-day or focused on historic events that explicitly connected to present-day concerns were considered to be Current. All case studies that focused on the United States as the primary location were considered to be U.S.-Centered. Case studies were determined to be U.S.-Centered even if the primary area of discussion was outside the U.S., as long as the case study specifically stated a connection to the U.S. (e.g., a case study about the consequences of mining for cell phone minerals abroad was considered to be U.S.-Centered, because it asked students to consider the environmental impact of their phones).

If case studies made explicit connections to the daily life of the target readership, then they were coded as containing the third Daily Life parameter, Everyday Life. For example, discussion of power plants was coded as connected to Everyday Life if the discussion included some of the ways people use electricity in Everyday Life (e.g., computers, refrigeration, etc.). If the discussion did not include these connections, then it was not coded as connecting to Everyday Life.

Daily Life (comprised of Current, U.S.-Centered and Everyday Life measures) is one variable in our second research question that focused on how textbooks link together the Ecology Disrupted variables: Daily Life, Human Impact, and Ecology. To explore this question, we also operationalized the other Ecology Disrupted variables: Human Impact and Ecology (Table 2). We broke the Human Impact variable down into two subcomponents: the Human Actions that affect the environment and the Environmental Impact of those actions. The Ecology element was based on a published list of ecological topics covered in environmental science courses (McComas, 2002; Table 2).

Our operationalization of Human Impact and Ecology corresponded to the definition of environmental science, the study of "the natural world and how humans interact with and impact it" (Karr et al., 2015, p. 5, emphasis added). Ecology emphasizes the ecological interactions that are the focus of environmental study of the natural world. Human Impact, broken into its two subcomponents, Human Action and Environmental Impact, corresponds to how humans interact with the environment and how humans impact it.

A case study was coded as containing Human Action if it described the behavior of society or people generally that can affect the environment (e.g., power plants to make electricity). This coding scheme meant that reference to Human Action was frequently coded as Human Action only and not Everyday Life, but reference to Everyday Life was frequently coded as both Everyday Life and Human Action. For example, agricultural or mining activities were coded as referring to Human Action, but not to Everyday Life. However, if a text referred to particular agricultural products people eat (e.g., wheat in the bread people consume) or the use of mining products in daily life (e.g., gold jewelry or coal for electricity in the home), then the example was coded as referencing both Human Action and Everyday Life.

For an item to be coded as relating to Environmental Impact, how people impact the environment must have been described (e.g., polluted waterways, deforestation). Environmental Impact was not coded as present in case studies that only described the effects of human actions on people. For example, the relationship between education and poverty in the developing world was coded as Human Action, but not as Environmental Impact (a similar approach was used in Simon et al., 2018).

As in the other categories, the ecological interactions referenced must have been explicit for the Ecology category to have been coded as present in the case study. For example, while a case study referring to polychlorinated biphenyl (PCB) pollution would be coded as referring to an Environmental Impact, it would not be coded as making an explicit connection to Ecology. 
TABLE 2. Codes used for content analysis to understand specificity (research question 1), and the elements of the Ecology Disrupted Framework (research question 2)

Specificity

All measures are additive: If position 3 is marked present, then position 2 and 1 are marked present. If position 2 is marked present, then position 1 is marked present.

\begin{tabular}{llll}
\hline & \multicolumn{1}{c}{$\mathbf{1}$} & \multicolumn{1}{c}{$\mathbf{2}$} & \multicolumn{1}{c}{$\mathbf{3}$} \\
\hline Location & Location & Primary Location & Specific Primary Location \\
Date & Generalized Date & Specific Date & \\
Data & Unrelated Data & Relational Data & Manipulable Data \\
\hline
\end{tabular}

The elements of Ecology Disrupted

\begin{tabular}{|c|c|c|}
\hline Daily Life & \multicolumn{2}{|c|}{ Three different parameters that measure the potential of case studies to be personalized to a student's prior experiences } \\
\hline Current & \multicolumn{2}{|c|}{ 1. Present-day } \\
\hline & \multicolumn{2}{|l|}{ 2. Historical, but explicitly connected to present-day concerns } \\
\hline U.S.-Centered & \multicolumn{2}{|l|}{ 1. U.S. locale is primary focus } \\
\hline Everyday Life & \multicolumn{2}{|l|}{ Explicit connection to the daily lives of target readership } \\
\hline Human Impact & \multicolumn{2}{|c|}{ The Human Actions that affect the environment and the Environmental Impact of those actions } \\
\hline Human Action & \multicolumn{2}{|c|}{ Behavior of society or people generally that affects the environment } \\
\hline Environmental Impact & \multicolumn{2}{|c|}{ How the environment is impacted by people } \\
\hline \multirow[t]{9}{*}{ Ecology } & 1. Abiotic/biotic factors & 9. Food webs/chains \\
\hline & 2. Bioaccumulation/biomagnification & 10. Evolution-natural selection \\
\hline & \multirow{2}{*}{$\begin{array}{l}\text { 3. Biogeochemical cycles (nitrogen, carbon, water } \\
\text { including runoff groundwater, etc.) }\end{array}$} & 11. Genetic diversity \\
\hline & & 12. Habitat (not destruction or loss) \\
\hline & 4. Biomes-aquatic and terrestrial & 13. Limited resources/competition/carrying capacity \\
\hline & 5. Community, biodiverse communities & 14. Niche \\
\hline & 6. Ecological succession (including climax community) & 15. Population dynamics (not population decline as species \\
\hline & 7. Ecosystems (not destruction, degradation, or loss) & loss synonym) \\
\hline & 8. Energy pyramid (trophic levels) & 16. Predator/prey/symbiosis \\
\hline
\end{tabular}

However, if the text clearly described how PCBs alter abiotic ecosystem components, it would be coded as relating to both Ecology and Environmental Impact. Furthermore, some case studies used ecological terms as synonyms for environmental impacts, not to describe ecological complexities. In those circumstances, the Environmental Impact was coded as present, but Ecology was coded as absent (see Table 2 for exceptions; e.g., species loss described as population decline, deforestation described as habitat loss).

\section{Interrater Reliability and Rater Background}

We evaluated the textbooks for the presence or absence of these key concepts. We have PhDs in biology, focus on ecology and evolution, and have taught environmental science and ecology and evolution courses multiple times. Before scoring items, we developed, calibrated, and adjusted rubrics based upon iterative review and discussion of individual sections and paragraphs of the main bodies of one secondary school-level textbook and one college-level textbook (Arms, 2008; Cunningham and Cunningham, 2013). Through this process, we determined to only code explicit category mentions, because codes for implicit category mentions could not be reliably replicated between coders. To measure interrater reliability, one textbook was analyzed separately, and each category compared for percent agreement. Overall interrater reliability was found to be $87.4 \%$, with the greatest level of agreement found for generic Location and Unrelated Data at $95.8 \%$ and $95.0 \%$, respectively, and the lowest level of agreement found for relating to U.S-Centered at $81.7 \%$ agreement. We also calculated Cohen's kappa (K), an agreement coefficient between raters that factors in agreement due to randomness (Cohen, 1960). According to this measure, any agreement above 0.60 is considered to be acceptable (McHugh, 2012). Cohen classified a kappa value between 0.61 and 0.80 as substantial and a kappa value of $0.81-1.00$ as almost perfect agreement. Our agreement coefficient values ranged from 0.62 to 0.93 . Agreement coefficients ranged from 0.75 to 0.89 for Everyday Life, Human Action, Environmental Impact, and Ecology. Disagreements were discussed until they were resolved.

For each textbook, we calculated the frequency of each code theme in the case studies. For cross-textbook comparisons, the frequency values were analyzed as percentages rather than as raw numbers, as case study number varied by textbook. We also determined the frequency of code co-occurrence to get a better sense of how frequently the Ecology Disrupted themes were linked to one another. Specifically, we examined case study co-occurrence among these Ecology Disrupted variables: 1) Daily Life (as measured by Everyday Life), 2) Human Impact (as measured by its Human Action and Environmental Impact subcomponents), and 3) Ecology.

The upper limits of calculated co-occurrence values were limited by the original frequency values for that theme. For example, the Ecology frequency value for Arms (2008) was six out of 21 case studies (29\%). Delving deeper into the Ecology theme showed that Ecology co-occurred with at least one other Ecology Disrupted variable in only half the case studies in which it was mentioned, meaning Ecology co-occurred with another variable in just three out of 21 case studies (14\% of case studies). Finally, the co-occurrence value fell to two out of 21 case studies (10\% of case studies) when case studies 


\section{Percent Presence of Specific Location, Date and Data}

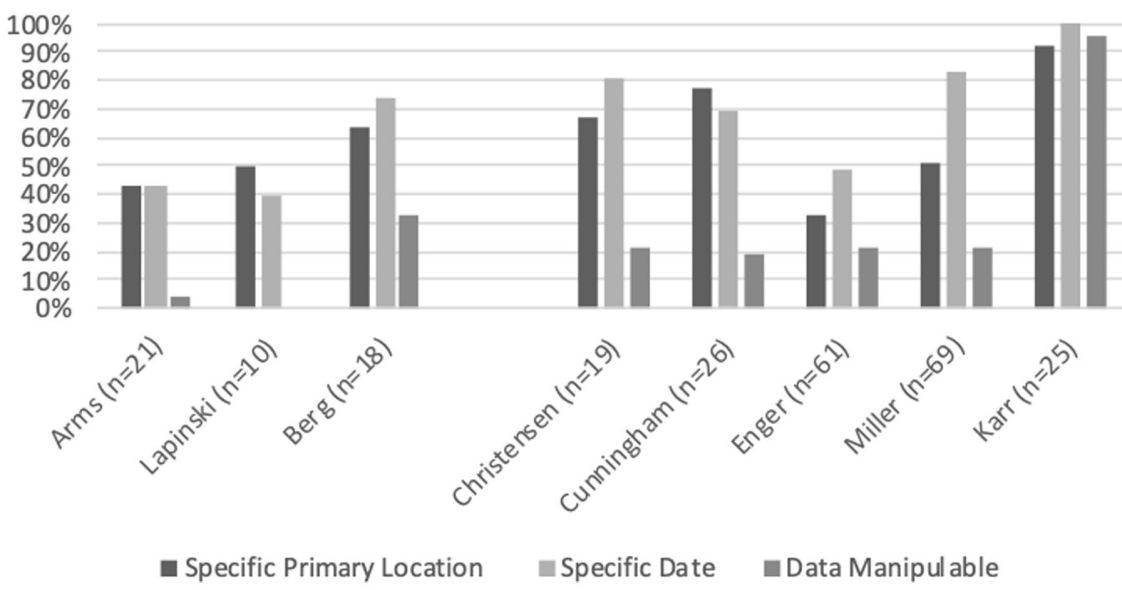

FIGURE 1. Measure of case study specificity through percent of case studies with identified Specific Locations, Specific Dates, and Data Manipulable. Key to textbook references: Arms et al., 2008; Lapinski et al., 2003; Berg et al., 2013; Christensen, 2012; Cunningham and Cunningham, 2013; Enger and Smith, 2016; Miller and Spoolman, 2013; Karr et al., 2015.

were assessed for how frequently Ecology was discussed in the context of all the other Ecology Disrupted variables together.

\section{RESULTS}

\section{Case Study Specificity}

This section reports results on the three parameters used to analyze textbooks for specificity: Specific Location, Date, and Data. Figure 1 shows results for the presence of the most specific form of each parameter, Specific Primary Location, Specific Date, and Manipulable Data.

Analysis of all textbooks combined showed that case studies tend to build specificity through mention of a Specific
Primary Location or a Specific Date rather than through the inclusion of Manipulable Data (all except Karr et al., 2015). Comparisons among textbooks showed that Karr et al.'s (2015) case studies are more specific than those in the other textbooks. The case studies include more Manipulable Data, more Specific Dates, and more Specific Primary Locations than the other textbooks. While Manipulable Data was only common in Karr, a Specific Primary Location and a Specific Date were frequently mentioned by all textbooks. However, some textbooks, like Karr et al. (2015), reference a Specific Primary Location and Specific Date in almost all case studies, while others, like Enger and Smith (2016), reference a Specific Primary Location only one-third of the time and a Specific Date only half the time.

To better understand data usage, we analyzed each case study for the type of data included (Figure 2). Two Unrelated Data points were considered to provide the least data, followed by two Relational Data points. Three or more Manipulable Data points were considered to provide the most detailed data. (As a reminder, case studies that contain Manipulable Data were also considered to contain Relational and Unrelated Data, and case studies that contain Relational Data were considered to contain Unrelated Data.) The analysis showed that a fairly high percentage of case studies from all textbooks include at least some Unrelated Data. There are fewer textbooks in which greater than $50 \%$ of case studies include Relational Data (Berg et al., 2013; Cunningham and Cunningham, 2013; Karr et al., 2015). However, only Karr et al.'s (2015) textbook contains a substantial percentage of case studies with Manipulable Data.

\section{Percent Data Unrelated, Relational and Manipulable}

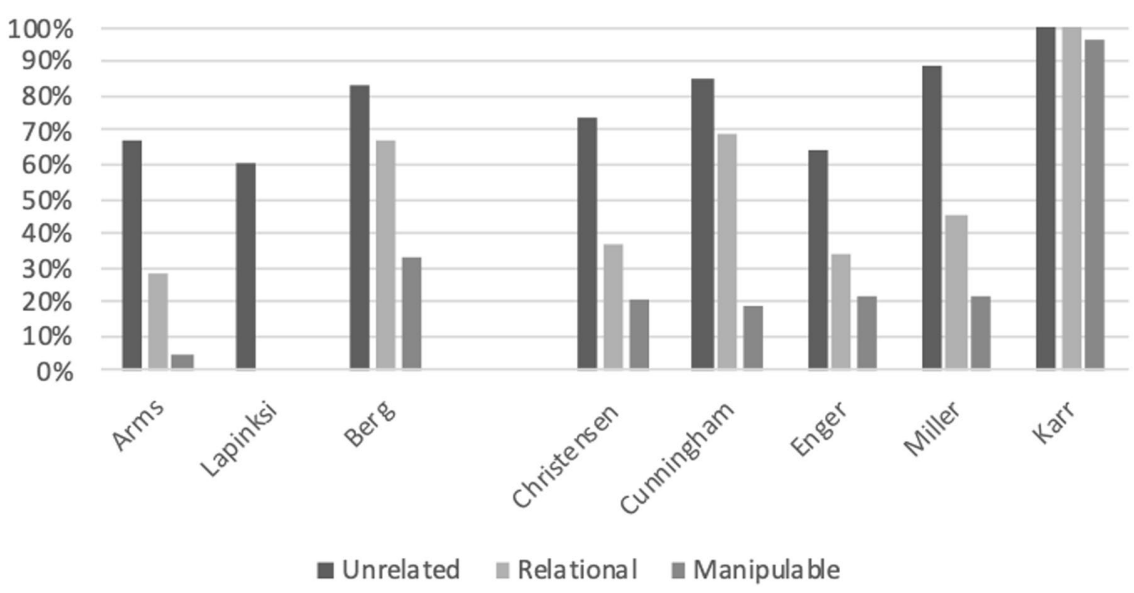

FIGURE 2. The percent of case studies by textbook that contain Unrelated Data, Relational Data, and Manipulable Data. See Figure 1 caption for a key to textbooks.

\section{Case Study Personalization to Students} Prior Daily Life Experiences

As a first approximation of case study personalization to student's prior Daily Life experiences, we analyzed textbooks for the percentage of Current case studies, for the percentage of case studies that are U.S.-Centered, and for the percentage of case studies that are both Current and U.S.-Centered (Figure 3). No major differences among textbooks were found for the items measured. Most case studies are Current, and the majority of case studies (except those from Cunningham) are U.S.-Centered. Fifty-nine percent of case studies from all the textbooks combined are Current and U.S.-Centered; however, fewer than half the case studies of three textbooks (Arms, 2008; Christensen, 2012; Cunningham and Cunningham, 2013) are Current and U.S.-Centered. 
Percent Case Studies Current, U.S.-Centered, Current + U.S.-Centered

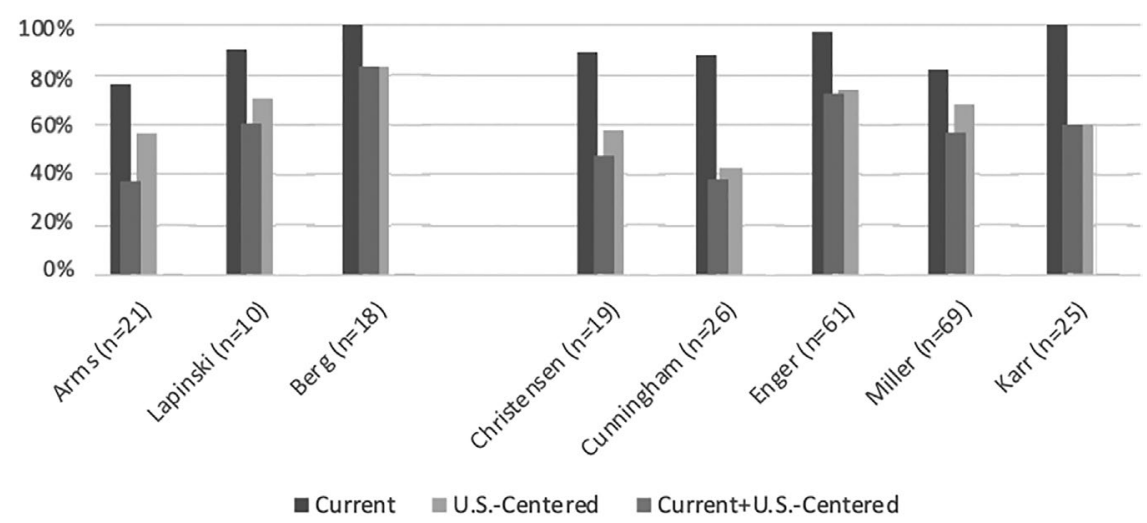

FIGURE 3. The percent of case studies by textbook that are Current, U.S.-Centered, and both Current and U.S.-Centered (Current + U.S.-Centered). See Figure 1 caption for a key to textbooks.

\section{What Do These Differences Look Like in Action?}

To get a better sense of how the differences in Dates, Location, Data, and Current, U.S.-Centered elements manifest in the case studies, we compare two rice-farming case studies from two different textbooks. The first case study (Lapinski et al., 2003, p. 222) focuses on small, nameless Chinese farms that cultivate rice without using expensive machinery, large-scale irrigation systems, or fertilizer. The case study does not contain any Dates or a U.S.-Centered location and does not connect to the Daily Life of U.S. students, particu- larly because the rice being grown is framed as feeding the people of China. It also does not include any quantitative Data.

In contrast, the other rice case study (Karr et al., 2015, pp. 318-319) provides a more finely drawn story. It tells the story about a rice-farming family that lives along the Sacramento River in Chico, California, and includes a map marking the location of the farm and the names of the farmers. The story begins in 1916, when the great-grandfather of today's family planted his first rice crop; moves to 1962 , when the family began instituting industrial agricultural practices like pesticides and human-made fertilizers; and then finishes with today's organic farm, which shuns pesticides and human-manufactured fertilizer, instead attracting natural predators to control pests and using manure to fertilize crops. The case study more explicitly connects to Daily Life of U.S. students by focusing on rice grown and consumed in the U.S. and by framing the rice produced as being sold in U.S. grocery stores along with other organic products students eat, like strawberries. It also contains Data that compare organic and conventionally grown products for antioxidant levels, shelf-lives, and pesticide residues. These details and the U.S.-Centered focus make the story more comprehensive and accessible to students' own prior experiences eating and buying grocery store foods.

\section{Percent Case Studies With Everyday Life, Human Action, Environmental Impact, Ecology}

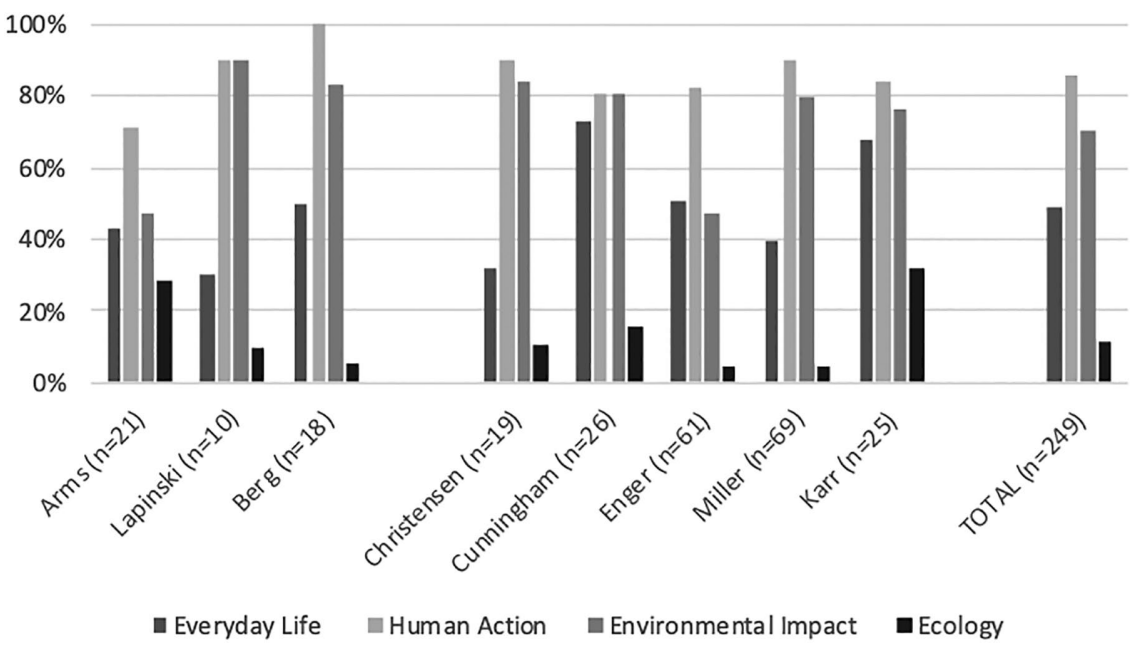

FIGURE 4. The percent of case studies by textbook and all textbooks combined that reference the Ecological Disrupted variables: Daily Life (as measured by Everyday Life), Human Impact (as measured by Human Action and Environmental Impact), and Ecology. Human Impact was present in $94 \%$ of the case studies. The remaining $6 \%$ of case studies focused on either Everyday Life only or Ecology only. See Figure 1 caption for a key to textbooks.

\section{Case Study Analysis for the Presence of} All Ecology Disrupted Elements

To gauge the presence of all Ecology Disrupted elements (Daily Life, Human Impact, Ecology) in the textbooks' case studies, we analyzed each case study for the presence or absence of the measures for the Ecology Disrupted elements: Daily Life (as measured by Everyday Life), Human Impact (as measured by its Human Action and Environmental Impact subcomponents), and Ecology (Figure 4). The primary focus of all books is on Human Impact (present in $94 \%$ of case studies, as measured by either its Human Action or Environmental Impact components), followed by Daily Life (as measured by Everyday Life), with lowest priority given to Ecology.

We also determined the frequency that Ecology Disrupted variables co-occur in case studies (Figure 5). We found that the Human Impact subcomponents, Human Action or Environmental Impact, most frequently co-occur, followed by Everyday Life, and then Ecology, which least frequently co-occurs with other topics. These findings indicate that Ecology is most 


\section{Percent Co-Occurence Between Everyday Life, Human Action, Environmental Impact, Ecology}

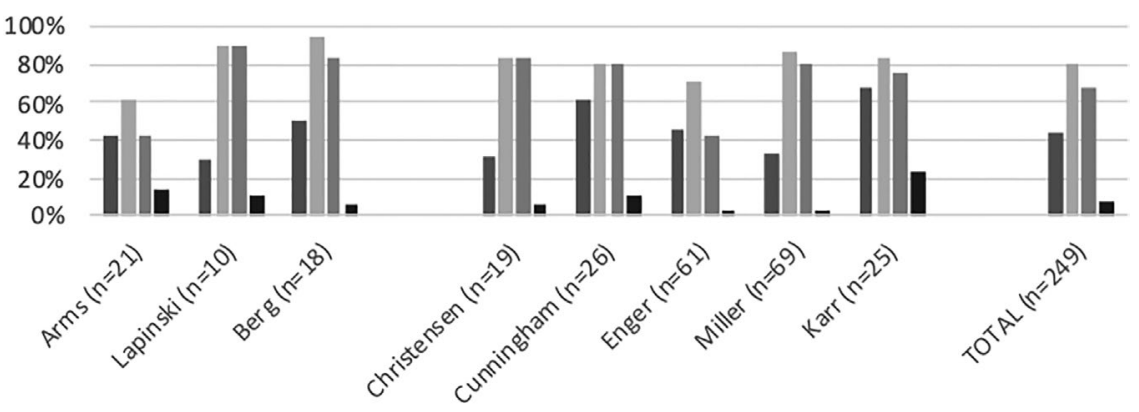

- Everyday Life + at least one other variable

- Hum an Action + at least one other varia ble

Environmental Impact + at least one other variable

- Ecology + at least one other variable

FIGURE 5. The percent of Ecology Disrupted variables in each case study by textbook and all textbooks combined that co-occur with other variables. Ecology Disrupted variables are measured by Everyday Life; the Human Impact subcomponents, Human Action and Environmental Impact; and Ecology. See Figure 1 caption for a key to textbooks. also determined the frequency with which Everyday Life and Ecology co-occur with and without the inclusion of the Human Impact subcomponents. We found that Human Impact subcomponents more frequently co-occur with Everyday Life than they do with Ecology. We found that, generally, case studies do not link Human Impact subcomponents to Ecology. We also found that Everyday Life and Ecology do not co-occur without the presence of the Human Impact subcomponents. In fact, we found that very few case studies link together all features of the Ecology Disrupted model: 1) Daily Life (as measured by Everyday Life), 2) Human Impact (as measured by its Human Action and Environmental Impact subcomponents), and 3) Ecology (Figure 6).

\section{What Do These Ecology and Daily Life Differences Look Like in Action?}

The Karr et al. textbook (2015, p. 260) provides an example of a case study that links all Ecology Disrupted elements: frequently discussed on its own and is least likely to be discussed with other topics.

Co-occurrence of Human Impact Subcomponents, Human Action and Environmental Impact, with Everyday Life or with Ecology

We determined the frequency with which the Human Impact subcomponents, Human Action or Environmental Impact (Figure 6), co-occurred with Everyday Life or Ecology, and we

1) Daily Life (as measured by Everyday Life), 2) Human Impact (as measured by its subcomponents, Human Action and Environmental Impact), and 3) Ecology. The case study uses Ecology to highlight how daily life and human behavior come together to impact the environment and drinking water of Anaheim, California. By embedding discussion of sewage treatment (Human Action) in the water cycle (Ecology) and the movement of treated water into depleted groundwater supplies (Environmental Impact/Ecology), the case study illustrates how people interact with natural systems. The case study is also personalized to students by asking readers to consider how they feel about drinking treated sewage (Everyday Life).

In contrast, other textbooks connect water overuse to only a subset of categories. For example, Arms (2008, pp. 272273) succeeds in connecting water overuse to Everyday Life, but does not make explicit the connections to Ecology. The Arms (2008) case study describes the connection between the agricultural crops people eat and water depletion in the Ogallala aquifer. However, because the case study does not develop the ecological connections, how water overuse relates to the larger movement of water through the ecosystem goes unexplored. Cunningham and Cunningham (2013, p. 373), Enger and Smith (2016, p. 354), and Miller and Spoolman (2013, p. 240) tell similar water overuse stories about Lake Mead and the western United States. Like Arms (2008), they too do not include the water cycle or other relevant ecological concepts, meaning that 
these case studies do not make explicit how people interact with ongoing ecological relationships and processes.

A different case study from Arms (2008, pp. 266-267) connects to all the Ecology Disrupted variables: Daily Life (as measured by Everyday Life), Human Impact (as measured by its Human Action and Environmental Impact subcomponents), and Ecology. This case study describes how Human Action is embedded in Everyday Life; in this case, the homes in which Americans live and the highways on which they drive impact wildlife through disruption of migratory corridor Ecology. In contrast, Enger and Smith (2016, p. 242) also connect Human Action and Environmental Impact to the Ecology of migratory corridors, but by using a distant location, the Serengeti, their case study does not challenge students to consider how their daily lives, in this case local roadways and highways, connect to the local environment.

Other case studies overlook connections to Current Everyday Life in the United States. Cunningham's case study about the environmental impact of bluefin tuna overfishing connects to the Human Action of upscale sushi consumption in Japan, a distant country, rather than connecting to U.S. consumption of overfished species. Additional case studies focus on the Environmental Impact of the Human Action of poaching elephants for ivory (Karr et al., 2015, p. 238; Cunningham and Cunningham, 2013, p. 539), the recovery of whales from long-ago hunting (Miller and Spoolman, 2013, p. 168), or the hunting of sharks for shark fin soup, a food most Americans do not consume (Miller and Spoolman, 2013, p. 61). Just one of the eight analyzed overexploitation case studies ties to Current Everyday Life in the United States by connecting menhaden overfishing in the Chesapeake Bay to the demand for fish oil in food students eat like margarine or as fish food for farmed fish that students might consume (Arms, 2008, pp. 396-397). However, this case study, like most of the case studies examined, does not explicitly connect to the Ecology of the Chesapeake, meaning that it misses the opportunity to explore how overconsumption of menhaden affects ecological interactions in the bay.

\section{DISCUSSION \\ Data and Specificity}

Our analysis of environmental science case studies in introductory textbooks shows variation in the level of specificity and data usage. The Karr et al. (2015) textbook shows the greatest level of specificity and data usage. Its case studies include more Specific Locations, more Dates, and more Data than the other textbooks. We argue that the extra details make for richer, more well-developed case studies, and they provide the necessary detail to make meaningful science stories (Herreid, 2007; Krulwich, 2008; Cron, 2012; Buckham, 2015; Koch, 2018). The benefit of richer stories is seen in the contrast between the two rice-farming stories (Lapinski et al., 2003; Karr et al., 2015). The Karr et al. (2015) case study contains rich details that bring the story to life, including Dates, a Specific Location, Data, and even the names of the farmers. The other case study (Lapinski et al., 2003) lacks all of these details. Without the details, the story it is too vague to truly engage learners (Cron, 2012; Buckham, 2015).

\section{Connecting to Daily Life}

We found that almost half of all textbook case studies explicitly connect to the Everyday Life of people in general and that a subset of these case studies focus on Current Everyday Life in the United States. In addition, we found that $59 \%$ of all case studies used Current U.S.-Centered examples. Engaging learners with case study content through lived experiences is the rationale for why we examined textbooks for the frequency of Everyday Life connections and Current U.S.-Centered examples (van den Broek, 2010). While we understand that many authors seek to expose readers to the global environment, we argue that current local examples are more likely to connect readers to the content and more likely to challenge students' assumptions about their daily life connections to the environment. For example, we argue that the local California rice farm case study, which included a map highlighting its location and a discussion comparing organic and nonorganic grocery store foods, would be easier for U.S. students to access than a generic story about small farms growing rice to feed the people of China.

If we want students to construct an understanding of the environment as including people, then textbooks need to present students with greater opportunities to see themselves in the environment (Premadasa and Bhatia, 2013; Rathburn, 2015; Hale et al., 2017). Examples from far-off locales are missed opportunities for students to see their own actions as being part of the environment. For instance, to challenge U.S. students' assumptions about their daily distance from the environment, we contend that it is more effective to link disrupted wildlife migratory corridors to interstate highways that crisscross the entire United States than to focus on roadbuilding in the Serengeti. Nevertheless, many international stories, like the Serengeti roadway story, are compelling and consequential. Authors should modify their global stories to make localized connections. In the case of the Serengeti, the story could easily be personalized to the U.S. experience by the inclusion of a question asking students to consider the impact on U.S. wildlife of the roads and highways students use daily.

This suggestion to localize foreign examples through personalization also applies to U.S. stories. For example, the rice-farming story from rural California may at first glance feel unrelated to the lives of students in urban Chicago. Yet the authors used a number of techniques to make the story relevant to all Americans. They included a map of the location, an opportunity to geographically orient the story to other areas of the United States, and they discussed the consumption of rice and strawberries sold at grocery stores, making the farm to table connection explicit. By referring to grocery stores, the authors give students an opportunity to consider how the food they buy in stores connects to rural farms in other parts of the United States.

Even though all textbook case studies could have been personalized to the daily lives of students in this manner, only half of textbook case studies explicitly connected to Everyday Life of people in general, and only a subset of these examples focused on Current Everyday Life in the United States. Many case studies can be effortlessly modified for greater connection to the target U.S. student audience. For example, the simple insertion into the Japanese bluefin tuna overfishing story of a question asking students to consider their own seafood consumption habits would likely help to personalize the bluefin tuna story to the daily lived experiences of U.S. students. By connecting students' prior experiences to case study concepts, environmental science textbooks can enhance their potential to improve learning (van den Broek, 2010; Premadasa and Bhatia, 2013; Rathburn, 2015; 
Hale et al., 2017). Making this connection to prior daily lived experience also has the potential to expand student conceptions of environmental issues from something unrelated to their lives (Loughland et al., 2002; Shepardson et al., 2007; Moseley et al., 2010; Tsurusaki and Anderson, 2010; Yavetz et al., 2014) to a more inclusive view of environmental issues that involve them. An example from Japan that does not reference U.S. environmental behavior puts the environmental "blame" on Japan. However, showing students that their own seafood consumption also has environmental consequences includes them in the environmental story, likely making it harder for students to see themselves as separate from the environment and making it hard to "blame" other people for the world's environmental problems (Wyner and DeSalle, 2010, 2013; Wyner, 2013, 2015; Premadasa and Bhatia, 2013; Hale et al., 2017).

It is for this reason that we strongly advocate for making personal connections to the environment in all environmental stories told, even stories that are ostensibly foreign. Because people affect all aspects of the environment, making the connection to the daily lived experiences of the target student population is straightforward. For example, invasive species discussions, even those that focus on the consequences of invasives to a distant locale, can link specific invasive species to shipping of specific goods students wear or use in their homes, or a discussion of fossil fuels can reference students' daily reliance on refrigeration, electricity, heating, and transportation.

\section{Connecting to Ecological Interactions}

With only $8 \%$ of case studies connecting Human Impact (either Human Action or Environmental Impact) to Ecology, we found that fewer case studies linked Human Impact to Ecology than linked Human Impact to Everyday Life (45\%). We also found even fewer case studies, just 3\%, that linked together all the Ecology Disrupted components: Daily Life (through measurement of Everyday Life), Human Impact (through measurement its Human Action or Environmental Impact subcomponents), and Ecology.

We argue that case studies would better develop the "people as part of nature" perspective if they linked together all Ecology Disrupted components: Daily Life, Human Impact, and Ecology. The Karr et al. (2015) water cycle/drinking water case study shows the utility of ecology for bridging students' perceptions of themselves as disconnected from the cycling of water in their environment. By explaining how water moves through the water cycle and then situating the movement of treated sewage water in the water cycle, the case study illustrates how drinking and sewage water interact with water cycle ecology. This method has the potential to chip away at the artificial boundary that separates people from the environment by bringing ecology in from the periphery and making it essential to the environmental story being told.

A number of textbooks described overfishing examples, but none connected Daily Life (as measured by Everyday Life), and Human Impact (as measured by its Human Action or Environmental Impact subcomponents) to Ecology. Yet overfishing is a good topic to illustrate the connection between daily life, human impact, and disrupted ecological interactions. For example, rather than telling a simple story of declining cod stocks and American dinner plates, incorporating marine food web trophic levels underscores the subtle interplay between people and marine ecosystems. Overfishing North Atlantic cod off the coast of New England has permanently reduced cod size, shifting cod's trophic position in the marine food web and permanently altering the abundance of lower trophic species (Jackson et al., 2001). The story of the disrupted cod food web can be a reminder to students that the isolated cod fillets they see laid out on ice were once key members of a larger ecosystem community.

Only a few textbooks link all the Ecology Disrupted variables: Daily Life (as measured by Everyday Life), Human Impact (as measured by its Human Action or Environmental Impact subcomponents), and Ecology. To better explain the utility of making these connections, we describe how to connect daily life and human impact to the nitrogen and carbon cycles, ecological topics covered in an isolated manner by most textbooks. Comparing the weight of naturally produced reactive nitrogen to the weight of reactive nitrogen produced by humans highlights the profound effect that people are having on nitrogen circulation. Knowing that people have doubled the worldwide quantity of circulating reactive nitrogen explains a host of environmental issues, most notably the widespread hypoxia in coastal waters around the world. For example, human-manufactured fertilizer applied to farms across the U.S. Midwest creates the annual summer Gulf of Mexico dead zone. The applied fertilizer is essential for producing the corn-raised cattle students eat and the ethanol fuel students rely on to get around, but it also creates dead zones by significantly boosting the amount of circulating nitrogen in Gulf Coast waters (Jackson, 2008).

In the same way that human manufacture of reactive nitrogen leads to its oversupply in the nitrogen cycle, so too does the burning of fossil fuels oversupply the carbon cycle with carbon dioxide. By burning fossil fuels, people are suddenly injecting into the carbon cycle carbon that was sequestered for millennia from the regular cycling of carbon. Just as understanding that doubling the amount of reactive nitrogen in circulation has consequences, seeing the contrast of the preindustrial and present-day carbon cycles makes the environmental consequences of increased carbon dioxide from burning fossil fuels less of a mystery. Tying fossil fuel use for life's daily needs, like electronic connectivity, transportation, and refrigerated foods, to the carbon cycle, emphasizes the centrality of ecological processes to human well-being. Making the ecological connections to daily life explicit has the potential to bring out people's absolute dependence on the environment.

\section{Limitations}

Study limitations include a small sample size of textbooks, variable publication dates, and using case studies as the only basis for textbook analysis. Case study length also varied among textbooks (e.g., high school-level case studies tended to be shorter than college-level case studies). In addition, case studies were not standardized across textbooks. For example, Enger and Smith's (2016) case studies were not called case studies. Furthermore, case studies from different textbooks potentially have learning goals at cross-purposes with the learning goals we investigated. These different goals may have caused them to score poorly on our rubric, because we did not measure features that matched the authors' learning goals. A good example of this weakness is the roadbuilding in the Serengeti case study. We marked this case study low in terms of how it connected to daily life in the United States, but the authors may have felt it was 
more important to make international connections. In addition, finding U.S.-themed case studies was a proxy for measuring personalization, not an exact measure of it. This means some of the U.S. stories may have felt just as distant from students as the international case studies. We tried to compensate for this weakness by also scoring case studies as U.S.-Centered when authors connected them to behaviors or events in the United States, but it was not possible to fully correct for this weakness. Also, our methodology did not allow measurement of implicit connections made by textbooks, potentially underplaying these connections. Finally, this study did not specifically investigate how case studies affect student learning.

\section{Summary}

We argue that study findings are most important for what they reveal about general patterns across textbooks. Like others, we found that environmental science textbooks underplay the human connection to the environment (Sullivan, 2008; Sharma and Buxton, 2015). Specifically, this study broadly documents how a range of textbooks underplay the connections of human impact and daily life to ecological interactions. In addition, our content analysis findings and case study descriptions illustrate potential approaches for improving the daily life-ecology connection and science story richness. By delving into specific case study narratives, this paper posits that textbook case studies can be improved:

1. With more data and details to tell more fleshed-out relatable stories, as shown in the contrast of the China and U.S. rice farming examples. The China example was vaguely reported and included no dates or data, whereas the U.S. example was fleshed out with data, dates, and specific locations.

2. By using more current and specific, local, place-focused examples. Textbooks should emphasize named places from the local context of the audience, and if they use faraway examples, they should make an effort to tie those environmental stories to the daily concerns of the target readership. For example, U.S. interstate highways could be connected to both the U.S. and Serengeti migration corridor stories.

3. By making more daily life connections. Asking students to apply what they learn to their local contexts may help challenge student perceptions of people as separate from the environment. For example, students can be asked to consider their seafood consumption habits in the context of the Japanese bluefin tuna overfishing story.

4. By sharing more stories that link daily life and human impact with ecological interactions. The explicit inclusion of ecological interactions into environmental stories about the impact of daily life has the potential to better explain how people interact with the rest of the living world. This linkage between daily life, human impact, and ecology is shown by the treated drinking water-water cycle story, the relationship between overfishing and shifting cod trophic levels example, the algal bloom impacts of doubling circulating reactive nitrogen for agriculture, and the carbon dioxide contrast between the present-day and preindustrial carbon cycles.

Research on student learning needs to be conducted to determine how these suggestions affect student learning. Studies on how environmental science case study features like specificity, personalization, and ecological linkages affect student learning and attitudes would be valuable for determining whether these suggestions for improvement positively impact student learning and student perceptions of their everyday connections to the natural world.

\section{ACKNOWLEDGMENTS}

This study was supported by a PSC-CUNY grant.

\section{REFERENCES}

Arms, K. (2008). Environmental science. New York: Holt, Rinehart, Winston. Berg, L. R., Hager, M. C., \& Hassenzahl, D. M. (2013). Visualizing environmental science. Hoboken, NJ: Wiley/National Geographic.

Berkowitz, A. R., Cid, C., Doherty, J., Ebert-May, D., Klemow, K., Middendorf, G., ... \& Pohlad, B. (n.d.) The 4-Dimensional Ecology Education (4DEE) framework. Retrieved September 11, 2020, from www.esa.org/4DEE/ framework/

Boersema, J. J., Barendse, G. W. J., Bertels, J., \& de Wit, A. E. (2001). Is it all in the books? An analysis of the content and scope of 12 environmental science books. International Journal of Sustainability in Higher Education, 2(4), 349-368.

Bowen, G. M., \& Roth, W. M. (2002). Why students may not learn to interpret scientific inscriptions. Research in Science Education, 32(3), 303-327

Buckham, M. (2015). A writer's guide to active setting: How to enhance your fiction with more descriptive, dynamic settings. Blue Ash, $\mathrm{OH}$ : Writer's Digest Books.

Castree, N. (2017). Speaking for the "people disciplines": Global change science and its human dimensions. Anthropocene Review, 4(3), 160-182.

Cardinale, B. J., Duffy, J. E., Gonzalez, A., Hooper, D. U., Perrings, C., Venail, P., ... \& Kinzig, A. P. (2012). Biodiversity loss and its impact on humanity. Nature, 486(7401), 59

Ceballos, G. M., Ehrlich, P. R., \& Dirzo, R. (2017). Biological annihilation via the ongoing sixth mass extinction signaled by vertebrate population losses and declines. Proceedings of the National Academy of Sciences USA, 114(30), E6089-E6096

Chiappetta, E. L., \& Fillman, D. A. (2007). Analysis of five high school biology textbooks used in the U.S. for inclusion of the nature of science. International Journal of Science Education, 29(15), 1847-1868.

Christensen, N. (2012). The environment and you. San Francisco: Benjamin Cummings.

Cohen, J. (1960). A coefficient of agreement for nominal scales. Educational and Psychological Measurement, 20(1), 37-46.

Corvalan, C., Hales, S., \& McMichael, A. J. (2005). Ecosystems and human well-being: health synthesis. Geneva, Switzerland: World Health Organization.

Cron, L. (2012). Wired for story: The writer's guide to using brain science to hook readers from the very first sentence. Berkeley, CA: Ten Speed Press.

Cunningham, W., \& Cunningham, M. A. (2013). Environmental science: A global concern. New York: McGraw Hill.

Ehrlich, P. R., \& Ehrlich, A. H. (2013). Can a collapse of global civilization be avoided? Proceedings of the Royal Society B: Biological Sciences, 280(1754), 20122845.

Enger, E., \& Smith, B. (2016). Environmental science: A study of interrelationships (14th ed.). New York: McGraw Hill.

Environmental Literacy Council. (2004). Science for environmental literacy: A review of advanced placement environmental science textbooks. Washington, DC.

Gosselin, D. C., Manduca, C., Bralower, T., \& Mogk, D. (2013). Transforming the teaching of geoscience and sustainability. Eos, 94(25), 221-222.

Haidt, J. (2012). The righteous mind: Why good people are divided by politics and religion. New York: Pantheon.

Hale, A. E., Shelton, C. C., Richter, J., \& Archambault, L. M. (2017). Integrating geoscience and sustainability: Examining socio-techno-ecological relationships within content designed to prepare teachers. Journal of Geoscience Education, 65(2), 101-112.

Herreid, C. F. (2007). Start with a story: The case study method of teaching college science. Arlington, VA: NSTA Press. 
Herreid, C. F., Schiller, N. A., Herreid, K. F., \& Wright, C. (2011). In case you are interested: Results of a survey of case study teachers. Journal of College Science Teaching, 40(4), 76-80.

Jablonski, L. M., Klemow, K., \& Puttick, G. (2015). Achieving energy and ecological literacies for all: Linking ecology and energy education. Perspectives from sessions at Ecological Society of America (ESA) 2014 Annual Meeting. Journal of Sustainability Education, 8.

Jackson, J. B. (2008). Ecological extinction and evolution in the brave new ocean. Proceedings of the National Academy of Sciences USA, 105, 11458-11465. doi: 10.1073 pnas.0802812105

Jackson, J. B. C., Kirby, M. X., Berger, W. H., Bjorndal, K. A., Botsford, L. W. Bourque, B. J., ... \& Warner, R. R. (2001). Historical overfishing and the recent collapse of coastal ecosystems. Science, 293, 629-638.

Karr, S., Houtman, A., \& Interlandi, J. (2015). Scientific American environmental science for a changing world. New York: Freeman.

Kesidou, S., \& Roseman, J. E. (2002). How well do middle school science programs measure up? Findings from Project 2061's curriculum review. Journal of Research in Science Teaching, 39(6), 522-549.

Klassen, S. (2010). The relation of story structure to a model of conceptual change in science learning. Science \& Education, 19(3), 305-317.

Koch, J. (2018). Science stories: Science methods for elementary and middle school teachers. Cengage Learning.

Krippendorff, K. (2013). Content analysis: An introduction to its methodology (3rd ed.). Thousand Oaks: SAGE Publications, Inc.

Krulwich, R. (2008). Tell me a story: Robert Krulwich's commencement speech at California Institute of Technology. Retrieved September 11, 2020, from www.wnycstudios.org/story/91852-tell-me-a-story

Lapinski, A. H., Schoch, R. M., \& Tweed, A. (2003). Environmental science, New York: Scott Foresman-Addison Wesley.

Lederman, N. G. (2013). Nature of science: Past, present, and future. In Abell, S. K., \& Lederman, N. G. (Eds.), Handbook of research on science education (pp. 831-879). Mahwah, NJ: Lawrence ErlbaumAssociates.

Leopold, A. (1949). A Sand County almanac, and sketches here and there New York: Oxford University Press.

Loughland, T., Reid, A., \& Petocz, P. (2002). Young people's conceptions of environment: A phenomenographic analysis. Environmental Education Research, 8(2), 187-197.

Lundeberg, M., \& Yadav, A. (2006a). Assessment of case study teaching: Where do we go from here? Part I. Journal of College Science Teaching, 35(5), 10-13.

Lundeberg, M., \& Yadav, A. (2006b). Assessment of case study teaching: Where do we go from here? Part II. Journal of College Science Teaching, 35(6), 8-13.

McComas, W. (2002). The ideal environmental science curriculum: History, rationales, misconceptions \& standards. American Biology Teacher, 64, 665-672.

McHugh, M. L. (2012). Interrater reliability: The kappa statistic. Biochemia Medica, 22(3), 276-282

MedCalc. (2018). MedCalc: Easy to use statistical software. Retrieved from www.medcalc.org/index.php

Miller, G. T., \& Spoolman, S. (2013). Environmental science (14th ed.) Belmont, CA: Brooks/Cole Cengage Learning.

Moseley, C., Desjean-Perrotta, B., \& Utleyb, J. (2010). The Draw-An-Environment Test Rubric (DAET-R): Exploring pre-service teachers' mental models of the environment. Journal of Environmental Education Research, 16(2), 189-208.

NGSS Lead States. (2013). Next generation science standards: For states, by states. Washington, DC: National Academies Press.

Noddings, N., \& Witherell, C. (1991). Epilogue: Themes remembered and foreseen. In Witherell, C., \& Noddings, N. (Eds.), Stories lives tell (pp. 279 280). New York: Teachers College Press.

Olsen, D. R. (1980). On the language and authority of textbooks. Journal of Communication, 30, 186-196.

Oosthoek, J., \& Gills, B. K. (2013). The globalization of environmental crisis. New York: Routledge.

Premadasa, K., \& Bhatia, K. (2013). Real life applications in mathematics: What do students prefer? International Journal for the Scholarship of Teaching and Learning, 7(2), 20.
Rathburn, M. K. (2015). Building connections through contextualized learning in an undergraduate course on scientific and mathematical literacy. International Journal for the Scholarship of Teaching and Learning, 9(1), n1.

Schlosser, P., \& Pfirman, S. (2012). Earth science for sustainability. Nature Geoscience, 5, 587-588.

Shapiro, A. R. (2012). Between training and popularization: Regulating science textbooks in secondary education. Isis, 103(1), 99-110.

Sharma, A., \& Buxton, C. A. (2015). Human-nature relationships in school science: A critical discourse analysis of a middle-grade science textbook. Science Education, 99(2), 261-281.

Shepardson, D., Wee, B., Priddy, M., \& Harbor, J. (2007). Students' mental models of the environment. Journal of Research in Science Teaching. 44, 327-348.

Simon, S. M., Meldrum, H., Ndung'u, E., \& Ledley, F. D. (2018). Representation of industry in introductory biology textbooks: A missed opportunity to advance STEM learning. CBE-Life Science Education, 17(4). https://doi. org/10.1187/cbe.17-03-0057

Sinaga, P., Kaniawati, I., \& Setiawan, A. (2017). Improving secondary school students' scientific literacy ability through the design of better science textbooks. Journal of Turkish Science Education, 14(4), 92-107.

Smith, B. L., Holliday, W. G., \& Austin, H. W. (2010). Students' comprehension of science textbooks using a question-based reading strategy. Journal of Research in Science Teaching, 47(4), 363-379.

Sullivan, J. (2008). The use of photographs to portray urban ecosystems in six introductory environmental science textbooks. Journal of Research in Science Teaching, 45, 1003-1020.

Torkar, G. (2009). Biology teachers' conceptions about nature and environment-two fundamental concepts of education for sustainable development. Acta Biologica Slovenica, 1(52), 61-68.

Tsurusaki, B. K., \& Anderson, C. W. (2010). Students' understanding of connections between human engineered and natural environmental systems. International Journal of Environmental \& Science Education, 5(4), 407-433.

Väljataga, T., \& Fiedler, S. H. (2014, June). Going digital: Literature review on E-textbooks. In International conference on learning and collaboration technologies (pp. 138-148). New York: Springer.

Valverde, G. A., Bianchi, L. J., Wolfe, R. G., Schmidt, W. H., \& Houang, R. T (2002). According to the book: Using TIMSS to investigation the translation of policy into practice through the world of textbooks. Dordrecht, Netherlands: Kluwer.

van den Broek, P. (2010). Using texts in science education: Cognitive processes and knowledge representation. Science, 328(5977), 453-456.

Vygotsky, L. S. (1962). Thought and language. Cambridge, MA: MIT Press.

Weiss, I. R., Pasley, J. D., Smith, P. S., Banilower, E. R., \& Heck, D. J. (2003). A study of K-12 mathematics and science education in the U.S. Chapel Hill, NC: Horizon Research.

Wyner, Y. (2013). A conceptual model for teaching the relationship of daily life and human environmental impact to ecological function. International Journal of Environmental \& Science Education, 8(4), 561-586

Wyner, Y. (2015). Ecology disrupted: Using sustainability as a unifying principle for an environmental science course. In Stratton, S., Hagevik, R., Feldman, A., \& Bloom, M. (Eds.), Educating science teachers for sustainability ( $p p$. 89-100). New York: Springer.

Wyner, Y., Becker, J., \& Torff, B. (2014). Explicitly linking human impact to ecological function in secondary school classrooms. American Biology Teacher, 76(8), 508-515.

Wyner, Y., \& Blatt, E. (2019). Connecting ecology to daily life: How students and teachers relate food webs to the food they eat. Journal of Biological Education, 53(2), 128-149.

Wyner, Y., \& DeSalle, R. (2010). Taking the conservation biology perspective to secondary school classrooms. Conservation Biology, 24, 649-654.

Wyner, Y., \& DeSalle, R. (2013). Bringing science out of the clouds. Genewatch, 26, 30-31.

Yavetz, B., Goldman, D., \& Péer, S. (2014). How do preservice teachers perceive "environment"and its relevance to their area of teaching? Environmental Education Research, 20(3), 354-371.

Yoho, R. A., \& Rittmann, B. E. (2018). Climate change and energy technologies in undergraduate introductory science textbooks. Environmental Communication, 12(6), 731-743. 